\title{
Contributors to This Issue
}

John W. Boyer is the Martin A. Ryerson Distinguished Service Professor of History at the University of Chicago (Department of History, 1126 E. 59th Street, Mailbox 122, Chicago, IL 60637; email: jwboyer@uchicago.edu). He is the author of Political Radicalism in Late Imperial Vienna: Origins of the Christian Social Movement, 1848-1897 (1981), Culture and Political Crisis in Vienna: Christian Socialism in Power, 1897-1918 (1995), Karl Lueger (1844-1910). Christlichsoziale Politik als Beruf. Eine Biografie (2010), and The University of Chicago: A History (2015). Together with Jan E. Goldstein, he is the editor of the Journal of Modern History. He is presently writing a political and social history of Austria from 1867 to 1983.

Luminita Gatejel is a researcher at the Institute for East and Southeast European Studies in Regensburg, Germany (Department of History, Landshuterstr. 4, 93047 Regensburg, Germany, email: gatejel@ios-regensburg.de). Her book, Warten, hoffen und endlich fahren. Auto und Sozialismus in der Sowjetunion, in Rumänien und der DDR (1956-1989/91), appeared in 2014. Her article is part of a larger project on the history of the Lower Danube in the nineteenth century.

Jefrrey Herf is Distinguished University Professor in the Department of History at the University of Maryland, College Park (2115 Francis Scott Key Hall, University of Maryland, College Park, MD 20742; email: jherf@umd.edu). His publications include Divided Memory: The Nazi Past in the Two Germanys (1997), The Jewish Enemy: Nazi Propaganda during World War II and the Holocaust (2006), Nazi Propaganda toward the Arab World (2009), and Undeclared Wars with Israel: East Germany and the West German Far Left, 1967-1989 (2016).

Mark W. Hornburg is a Ph.D. candidate in modern European history at the University of North Carolina at Chapel Hill (Department of History, Hamilton Hall, CB\#3195, UNCCH, Chapel Hill, NC 27599; email: hornburg@email.unc.edu). His dissertation, "Cleansing the Wehrmacht: The Treatment of Social Outsiders in the German Military under the Nazi Regime," examines differences between policy and praxis in the Wehrmacht's application of Nazi racial and social policy to its own men. He is also coeditor of the forthcoming volume, Beyond "Ordinary Men": Christopher Browning and Holocaust Historiography.

FABIAN LINK is assistant professor at the Goethe University Frankfurt (Department of History, History of Science, IG-Farbenhaus, Norbert-Wollheim-Platz 1, 60629 Frankfurt am Main, Germany; email: f.link@em.uni-frankfurt.de). He is the author of Burgen und 
Burgenforschung im Nationalsozialismus. Wissenschaft und Weltanschauung 1933-1945 (2014), and "Castle Studies and the Idea of Europe: Medievalism in German-Speaking Europe between Politics and Scientific Research, 1918-1945," which appeared in 2015 in German Studies Review. His current project, "The Epistemic-Political Constitution of West German Democracy," explores the history of the social sciences in West Germany during the early Cold War.

Julia Roos is associate professor of history at Indiana University, Bloomington (Department of History, Indiana University, Ballantine Hall 742, 1020 E. Kirkwood Ave., Bloomington, IN 47405; e-mail: roos@indiana.edu).She is the author of Weimar through the Lens of Gender: Prostitution Reform, Woman's Emancipation, and German Democracy, 1919-1933 (2010) and, most recently, a number of articles on the 1920s "black horror" propaganda campaign against France's colonial occupation troops in the Rhineland. Her current project is a book-length biography of "Erika Diekmann," tentatively titled, German Racial Regimes in the Twentieth Century: An Afro-German Microhistory.

WILLEKE SANDLER is assistant professor of history at Loyola University Maryland (Department of History, 4501 N. Charles Street, HU 314, Baltimore, MD 21210; email: wsandler@ loyola.edu). She is the author of "Deutsche Heimat in Afrika: Colonial Revisionism and the Construction of Germanness Through Photography," in the Journal of Women's History (Spring 2013), and "'Here too lies our Lebensraum': Colonial Space as German Space," in Heimat, Region, and Empire: Spatial Identities under National Socialism, ed. Claus-Christian W. Szejnmann and Maiken Umbach (2012). She is currently completing a book manuscript on the public activities of colonial lobbying organizations in Nazi Germany. 


\section{FORTHCOMING}

Volume 49

Number 3

2016

LETTER FROM THE EDITOR

MEMORial

Fritz Stern (1926-2016)

Volker Berghahn

ARticLES

Nation Objects: Monuments, Kitsch, and the Sense of Nation in Imperial Germany, 1871-1914 Helmut Walser Smith

Older German Officers and National Socialist Activism: Evidence from the German Volkssturm David K. Yelton

Paradoxes of Ostpolitik: Reconsidering the Moscow and Warsaw Treaties of 1970 William Glenn Gray

REVIEW Essays

"Bad" Politics and "Good" Culture: History and Emplotment of the Weimar Republic Jochen Hung

Nicholas Stargardt, The German War, A Nation under Arms, 1939-1945: Citizens and Soldiers Shelley Baranowski

BOOK REVIEWS 


\section{CAMBRIDGE}

\section{THE BEST IN GERMAN STUDIES}

\section{What Ifs of Jewish \\ History}

From Abraham to Zionism

Gavriel D. Rosenfeld, Editor

\section{The Extermination of}

the European Jews*

Christian Gerlach

New Approaches to

European History

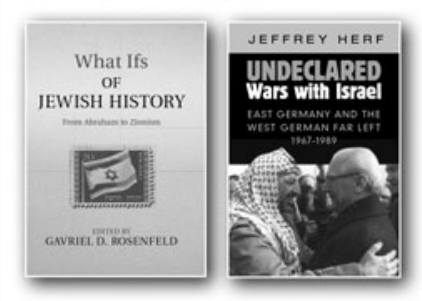

The Making of

an SS Killer*

The Life of Colonel

Alfred Filbert, 1905-1990

Alex J. Kay

The Red Army and the

Second World War

Alexander Hill

Armies of the Second World War

Undeclared Wars

with Israel*

East Germany and the

West German Far Left,

1967-1989

Jeffrey Herf

Why Switzerland?*

Third Edition

Jonathan Steinberg

\section{PUBLICATIONS OF THE \\ GㅈMN \\ HISTORICAL \\ INSTITUTE}

Bavarian Tourism and the Modern World, 1800-1950

Adam T. Rosenbaum

Paying for Hitler's War The Consequences of Nazi Hegemony for Europe

Edited by Jonas Scherner and Eugene N. White

Nuclear Threats, Nuclear Fear and the Cold War of the 1980s Edited by Eckart Conze, Martin Klimke, and Jeremy Varon
Thieves in Court

The Making of the German Legal System in the Nineteenth Century Rebekka Habermas

\section{NOW IN PAPERBACK!}

Gls in Germany

The Social, Economic, Cultural, and Political History of the American Military Presence Edited by Thomas W. Maulucci, Jr, and Detlef Junker

German Merchants in the NineteenthCentury Atlantic Lars Maischak

Nazi Crimes and the Law Edited by Nathan Stoltzfus and Henry Friedlander

\section{Export Empire} German Soft Power in Southeastern Europe, 1890-1945

Stephen G. Gross

New Studies in

European History

The Italian Renaissance in the German Historical Imagination, 1860-1930

Martin A. Ruehl Ideas in Context

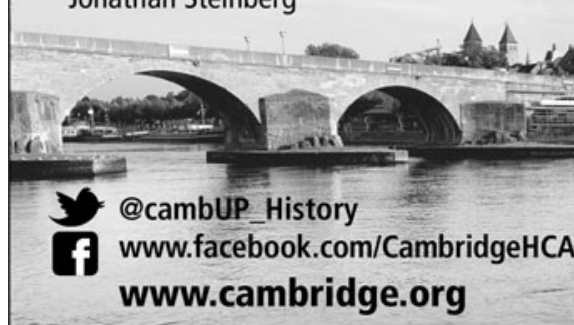

The Frankfurt School, Jewish Lives, and Antisemitism Jack Jacobs

Sex, Freedom, and Power in Imperial Germany, 1880-1914 Edward Ross Dickinson Available in paperback

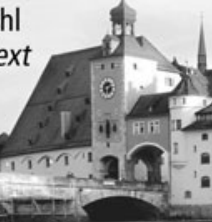




\section{CAMBRIDGE JUUNALS}

\section{Austrian History Yearbook}

Published for the Center for Austrian Studies, University of Minnesota

\section{Executive Editor}

Howard Louthan, University of Minnesota, USA

Editor

Daniel Unowsky, University of Memphis, USA

Founded in 1965 by R. John Rath, the Austrian History Yearbook remains the only English-language peerreviewed journal devoted to the history of the territories in Central Europe that were formerly under Habsburg rule and now comprise the modern states of Austria, the Czech Republic, Slovakia, Hungary, Slovenia, Croatia, Bosnia-Herzegovina and parts of Italy, Poland, Ukraine, Romania and Serbia. Typically, each issue of the Yearbook contains seven to eight articles, a forum on an important historical issue, a review article, and approximately 40 book reviews

AUSTRIAN
HISTORY
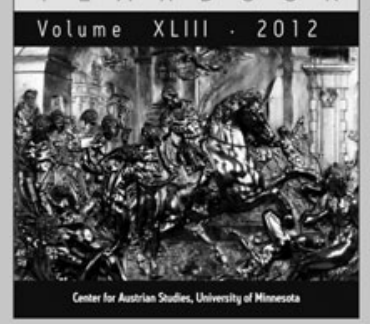

Austrian History Yearbook

is available online at:

http://journals.cambridge.org/ahy

To subscribe contact Customer Services

in Cambridge:

Phone +44 (0)1223 326070

Fax +44(0)1223 325150

Email journals@cambridge.org

\section{in New York:}

Phone +1 (212) 3375000

$\mathrm{Fax}+1$ (212) 3375959

Email

subscriptions_newyork@cambridge.org

\section{Free email alerts}

Keep up-to-date with new material - sign up at

journals.cambridge.org/ahy-alerts 


\section{Editorial Policy}

Central European History publishes articles, review articles, book reviews, and conference reports dealing with the history of German-speaking central Europe. The journal solicits manuscripts using all approaches to history and dealing with all historical periods. Because space is limited, articles that have been or soon will be published elsewhere are not accepted. Manuscripts submitted to CEH should not be under consideration by another journal pending decision of the editor on publication. If it is learned that an article is under submission to another journal while being considered at $\mathrm{CEH}$, consideration will cease immediately. Unsolicited book reviews are not accepted.

\section{Manuscripts and correspondence should be directed to:}

Andrew I. Port

Editor, Central European History

Wayne State University

$3094 \mathrm{FAB}$

656 West Kirby

Detroit, MI 48202, USA

Email: CentralEuropeanHistory@wayne.edu

The editors prefer that manuscripts be submitted in electronic form as email attachments sent to the journal's address, preferably in Microsoft Word 2003 or later or WordPerfect 12.0 or later; Adobe Acrobat pdf files will also be reviewed. Manuscripts submitted in printed form must be accompanied by a compact disk or diskette with the article in Word, WordPerfect, or pdf. The entire text of all manuscripts, including footnotes and headings, must be prepared in double-spaced typescript with generous margins to allow for copyediting. Footnotes must be numbered consecutively and should be placed in a separate section at the end of the text.

Correspondence concerning book reviews should be sent to:

Julia S. Torrie

Associate Editor, Book Reviews

Central European History

St. Thomas University

51 Dineen Dr.

Fredericton, NB

E3B 5G3

Canada

Email: ceh@stu.ca

Further guidelines for the preparation of manuscripts for publication in Central European History will be sent upon acceptance of materials by the editor. All materials will be edited to conform with The Chicago Manual of Style in matters regarding punctuation, capitalization, and format. The final decision on style remains with the editor. 


\section{Cambridge Journals Online}

For further information about this journal please

go to the journal web site at:

journals.cambridge.org/ccc

\section{CAMBRIDGE \\ UNIVERSITY PRESS}

